SAMPAIO, IMG; GUIMARÃES, MA; RABELO, JS; VIANA, CS; MACHADO, FGA. 2021. Productive and physiological responses of basil to nitrogen fertilization. Horticultura Brasileira 39: 335-340. DOI: http://dx.doi.org/10.1590/s0102-0536-20210315

\title{
Productive and physiological responses of basil to nitrogen fertilization
}

\author{
Italo MG Sampaio ${ }^{1 \mathbb{D}}$; Marcelo de A Guimarães ${ }^{2} \mathbb{D}$; Janiquelle da S Rabelo ${ }^{2} \mathbb{D}$; Caris dos S Viana ${ }^{2} \mathbb{D}$; Francisca \\ GA Machado ${ }^{2} \mathbb{D}$
}

${ }^{1}$ Universidade Federal Rural da Amazônia, Instituto de Ciências Agrárias (UFRA-ICA), Belém-PA, Brasil; italofito@gmail.com; ${ }^{2}$ Universidade Federal do Ceará, Centro de Ciências Agrárias (UFC-CCA), Fortaleza-CE, Brasil; mguimara@ufc.br; rabelojs@homail.com; carisviana@ hotmail.com; gislene.fga@gmail.com

\begin{abstract}
The aim of this study was to evaluate productive and physiological traits of basil cv. Italiano Genovese grown in nitrogen-fertilized soil. We studied five doses of nitrogen $\left(25,50,75,100\right.$ and $\left.125 \mathrm{~kg} \mathrm{ha}^{-1}\right)$, in urea form. The experimental design was completely randomized, with four replicates. The maximum plant height was $79 \mathrm{~cm}$, applying $65.7 \mathrm{~kg} \mathrm{ha}^{-1} \mathrm{~N}$. Shoot fresh and dry masses $\left(814.1 \mathrm{~g} \mathrm{plant}^{-1}\right.$ and 111.4 g plant ${ }^{-1}$, respectively) and productivity $\left(4.4 \mathrm{t} \mathrm{ha}^{-1}\right)$ reached maximum values at $86.2 ; 80.2$ and $82.5 \mathrm{~kg} \mathrm{ha}^{-1} \mathrm{~N}$, respectively. The highest $\mathrm{N}$ content in plant shoot was $26.1 \mathrm{~g} \mathrm{~kg}^{-1}$ at $125 \mathrm{~kg} \mathrm{ha}^{-1} \mathrm{~N}$. Photosynthesis and instantaneous carboxylation efficiency obtained maximum responses at doses of 85.3 and $83.3 \mathrm{~kg} \mathrm{ha}^{-1} \mathrm{~N}$, respectively. Stomatal conductance and transpiration increased with $\mathrm{N}$ additional rates.
\end{abstract}

Keywords: Ocimum basilicum, nitrogen, gas exchange.

\section{RESUMO}

Respostas fisiológicas e produtividade do manjericão em função da adubação nitrogenada

Objetivou-se com este estudo avaliar características fisiológicas e produtividade do manjericão cv. Italiano Genovese cultivado em campo e adubado com nitrogênio. Estudaram-se cinco doses de nitrogênio $\left(25,50,75,100\right.$ e $\left.125 \mathrm{~kg} \mathrm{ha}^{-1}\right)$, na forma de ureia. $\mathrm{O}$ delineamento experimental foi em blocos casualizados, com quatro repetições. A altura máxima das plantas foi de $79 \mathrm{~cm}$, sob a dose de $65,7 \mathrm{~kg} \mathrm{ha}^{-1} \mathrm{de} \mathrm{N}$. As massas frescas e secas da parte aérea $(814,1 \mathrm{~g}$ planta $^{-1}$ e 111,4 g planta $^{-1}$, respectivamente $)$ e a produtividade $\left(4,4 \mathrm{tha}^{-1}\right)$ atingiram valores máximos sob as doses de 86,$2 ; 80,2$ e $82,5 \mathrm{~kg} \mathrm{ha}^{-1} \mathrm{de}$ $\mathrm{N}$, respectivamente. $\mathrm{O}$ maior teor de $\mathrm{N}$ na parte aérea das plantas foi de $26,1 \mathrm{~g} \mathrm{~kg}^{-1}$ obtido sob a dose de $125 \mathrm{~kg} \mathrm{ha}^{-1}$ de N. A fotossíntese e a eficiência instantânea de carboxilação obtiveram máximas respostas sob as doses de 85,3 e $83,3 \mathrm{~kg} \mathrm{ha}^{-1}$ de $\mathrm{N}$, respectivamente. Para a condutância estomática e a transpiração observou-se aumento com acréscimo das doses de nitrogênio.

Palavras-chave: Ocimum basilicum, nitrogênio, trocas gasosas.

Received on August 7, 2020; accepted on June 18, 2021

$\mathrm{B}$ asil (Ocimum basilicum, Lamiaceae) is an herbaceous perennial plant, of great economic importance (Luz et al., 2009). This herb is very appreciated in worldwide cuisine. It can be consumed in natura, as dehydrated spice, for meat, fish, chicken, salads, soups, filling, as an ingredient in pasta and Italian sauce or as raw material for industrial processing. It can also be used in candies, liqueurs, in flavoring foods and beverages, as cosmetic, fungicide, insecticide and bactericide (Paiva et al., 2011; Pereira \& Moreira, 2011; Veloso, 2012; Beatović et al., 2015).

The crop's nutritional management is one of the factors that is responsible for productive traits of basil (Acharya et al., 2020). Nitrogen (N) stands out as the most required mineral for basil crop. This nutrient plays a fundamental role in many plant cell components (Taiz et $a l .$, 2017), that is to say, it is essential for development and reproduction of the plant (Leghari et al., 2016). When N is properly supplied, we verify positive gains in production and quality of leafy vegetables, such as basil (Argyropoulou et al., 2015; Ferreira et al., 2016; Rahimikhoo et al., 2020), since this nutrient participates in the biosynthesis of amino acids and proteins, nitrogen bases, plant membranes and hormones (Marschner, 2012). Despite the above, as the soils in Brazil, in general, show small amount of $\mathrm{N}$, fertilizer application is always indispensable (Jadon et al., 2018).
In general, an appropriate nitrogen application has a positive effect on vital physiological and biochemical processes for growing and development of the crops (Marschner, 2012; Taiz et al., 2017). As observed by Bassi et al. (2018), an appropriate N supplement increases the photosynthetic apparatus and, consequently, the chlorophyll content, the amount and activity of carboxylation enzymes, total protein, sugar content, total $\mathrm{N}$ and metabolites related to photosynthesis. Thus, the photosynthetic machinery is responsible for part of $\mathrm{N}$ content in the leaf (Lambers et al., 2008) being the photosynthetic capacity associated with the availability of this nutrient in plant tissues.

In relation to $\mathrm{N}$ quantity required 
and applied to basil crops, variations in doses have been observed in previous studies (Ferreira et al., 2015, 2016; Rahimikhoo et al., 2020). Argyropoulou et al. (2015) showed that photosynthesis, transpiration and stomatal conductance were reduced in basil plants under low concentrations of $\mathrm{N}$ in a nutrient solution. Therefore, these authors verified that the primary metabolism of this crop is extremely limited by $\mathrm{N}$ availability. On the other hand, Sifola \& Barbieri (2006) verified that high amounts of nitrogen fertilizer in soil allowed higher productive yields both for fresh mass and for essential oil.

Given the above, a diagnosis based on basil $\mathrm{N}$ demand is necessary, making $\mathrm{N}$ fertilizer more efficient related to physiological and productive traits and also to reduce the risk of waste in the environment (Ferreira et al., 2016; Ruan et al., 2016, Bassi et al., 2018). Thus, excessive levels of $\mathrm{N}$, as well as accumulation (luxury consumption) or tissue deficiency should be avoided.

Considering the information, in this study, we evaluated the physiological behavior and productivity of basil cv. Italiano Genovese related to increasing $\mathrm{N}$ doses applied to soil.

\section{MATERIAL AND METHODS}

The experiment was carried out in the field, in the Department of Phytotechnics, in Centro de Ciências Agrárias, at Universidade Federal do Ceará, Pici Campus, Fortaleza-CE (3⒋'37'S, 38 34'25'W, altitude 22 $\mathrm{m})$, from September to December, 2015. The local climate is 'As', according to Köppen, dry summer tropical climate. Average annual temperature was $27^{\circ} \mathrm{C}$ and rainfall 1,450 $\mathrm{mm}$ (Alvares et al., 2013).

The experimental design was randomized blocks, with four replicates and five treatments $(25,50,75,100$ and $125 \mathrm{~kg} \mathrm{ha}^{-1} \mathrm{~N}$ ). Three split doses of $\mathrm{N}$ were applied, considering that $50 \%$ of this dose was applied at planting and two split doses of $25 \%$ in top-dressing, at 10 and 20 days after transplanting. We used urea as fertilizer source, diluted in water. Urea was applied between rows, directly to soil, with a water can. The plot consisted of eight plants in double rows, spaced $0.60 \mathrm{~m}$ between rows and $0.30 \mathrm{~m}$ between plants, considering four central plants as useful area. The border line consisted of two plants between treatments, keeping the same spacing used for the useful plants.

The basil seeds (cv. Italiano Genovese) were sown in 162 cells polystyrene trays, filled with substrate containing compost and vermiculite in a ratio of 9:1 $\left(\mathrm{v} \mathrm{v}^{-1}\right)$, respectively, showing the following chemical composition in macronutrients (\%): $0.70 \mathrm{~N} ; 0.20 \mathrm{P}$; $0.40 \mathrm{~K} ; 1.00 \mathrm{Ca} ; 0.60 \mathrm{Mg}$ and $0.16 \mathrm{~S}$; and micronutrients (ppm): $9.4 \mathrm{~B} ; 18.00$ $\mathrm{Cu}$; $95.60 \mathrm{Fe}$; $133.00 \mathrm{Mn}$ and 105.00 $\mathrm{Zn}$. The trays were kept in a shelter covered with $30 \%$ shading screen. At 30 days after sowing, when the seedlings showed four-six definitive leaves, they were transplanted into the field.

For soil preparation, tillage system was used and seedbeds (pre-formed) were prepared manually, up to $0.2 \mathrm{~m}$ depth. Afterwards, we incorporated $12 \mathrm{~L} \mathrm{~m}^{-2}$ of organic compost. The compost consisted of plant material and cattle manure, with the following attributes in relation to contents of macronutrients (\%): $0.80 \mathrm{~N} ; 0.26 \mathrm{P} ; 0.41$ $\mathrm{K} ; 0.83 \mathrm{Ca} ; 0.11 \mathrm{Mg}$ and $0.14 \mathrm{~S}$; and micronutrients (ppm): $38.70 \mathrm{~B} ; 48.00$ $\mathrm{Cu} ; 603.00 \mathrm{Fe} ; 77.00 \mathrm{Mn}$ and 62.00 $\mathrm{Zn}$. The soil chemical characteristics after the compost incorporation (up to $0.2 \mathrm{~m}$ depth) were: $\mathrm{pH}=6.7 ; \mathrm{P}=261.4$ $\mathrm{mg} \mathrm{dm}{ }^{-3} ; \mathrm{K}^{+}=240 \mathrm{mg} \mathrm{dm}^{-3} ; \mathrm{Ca}^{2+}=9.9$ $\mathrm{cmol} \mathrm{dm}_{\mathrm{c}} \mathrm{dm}^{-3} \mathrm{Mg}=4.2 \mathrm{cmol}_{\mathrm{c}} \mathrm{dm}^{-3} ; \mathrm{Al}^{3+}$ $=0.0 \mathrm{cmol} \mathrm{dm}^{-3} ; \mathrm{H}+\mathrm{Al}=0.83 \mathrm{cmol}_{\mathrm{c}}$ $\mathrm{dm}^{-3} ; \mathrm{V} \%=95 ;$ and $\mathrm{M} . \mathrm{O}=4.7 \mathrm{dag} \mathrm{kg}^{-1}$.

Weeds were controlled by hand hoeing at weekly intervals and irrigation was performed daily, through microsprinkler irrigation system with flow rate of $126 \mathrm{~L} \mathrm{~h}^{-1}$, in two watering shifts, of 10 minutes each. No pests and/or diseases were verified throughout the crop cycle.

We evaluated the plant physiological traits, 30 days after seedling transplanting, using fully expanded leaves. The evaluated traits were: stomatal conductance $\left(g s-\mu \mathrm{mol} \mathrm{H}_{2} \mathrm{O}\right.$ $\left.\mathrm{m}^{-2} \mathrm{~s}^{-1}\right)$, leaf transpiration rate $(E-$ mmol $\left.\mathrm{H}_{2} \mathrm{O} \mathrm{m}^{-2} \mathrm{~s}^{-1}\right)$, net photosynthetic rate $\left(A-\mu \mathrm{mol} \mathrm{CO} \mathrm{m}_{2}^{-2} \mathrm{~s}^{-1}\right)$, internal carbon dioxide concentration ( $\mathrm{Ci}$ $\mu \mathrm{mol} \mathrm{CO} \mathrm{mol}^{-1}$ ), ratio between internal and environmental carbon dioxide concentrations $(\mathrm{Ci} / \mathrm{Ca})$. Based on $\mathrm{A}$ and $C i$ data, instantaneous carboxylation efficiency was determined by the ratio between $A$ and $C i(A / C i)$. An infrared gas analyzer (IRGA), model ADC, LCi (Analytical Development Co. Ltd., Hoddesdon, UK) was used. The evaluations were performed from 8 a.m. to 11 a.m. using artificial light $(1,000$ $\left.\mu \mathrm{mol} \mathrm{m} \mathrm{m}^{-2} \mathrm{~s}^{-1}\right)$ and $\mathrm{CO}_{2}$ concentration of $400 \mathrm{ppm}$ in the equipment chamber. During the evaluations the room temperature ranged from 28 to $32^{\circ} \mathrm{C}$.

Before harvesting, plant height was measured using a measuring tape, considering the soil surface up to the inflorescence insertion (Ferreira et al., 2015). At 32 days after transplanting, the plants were picked up; afterwards, fresh mass and shoot area were separated. These values were used to calculate the productivity $\left(\mathrm{t} \mathrm{ha}^{-1}\right)$. In order to obtain shoot dry mass, the material was put in a paper bag and then kept in a forced air circulation oven, at $65^{\circ} \mathrm{C}$, until reaching constant weight. To determine the masses, we used a scale with accuracy to 0.001 decimal places.

For determining the total nitrogen content, dried shoot samples were ground in a Willey mill, sieved through 20-mesh sieve and kept in paper bags. Sulfuric digestion method was used for this analysis, and $\mathrm{N}$ content was determined by the Kjeldahl method (Silva, 2009).

Obtained data were submitted to variance analysis; when significant by $F$ test $(p<0.05)$, data were submitted to regression analysis testing the models and respective coefficients by t-student test. All analyses were done using Sisvar ${ }^{\circledR}$ statistical software (Ferreira, 2011).

\section{RESULTS AND DISCUSSION}

Nitrogen fertilizer affected the traits related to gas exchanges of basil plants; the fertilization did not affect the internal $\mathrm{CO}_{2}$ concentration $(\mathrm{Ci}), \mathrm{Ci} / \mathrm{Ca}$ ratio, growth and productivity, though.

Gas exchanges, photosynthesis (Figure 1a) and instantaneous carboxylation efficiency (Figure $1 b)$ showed the maximum rates 


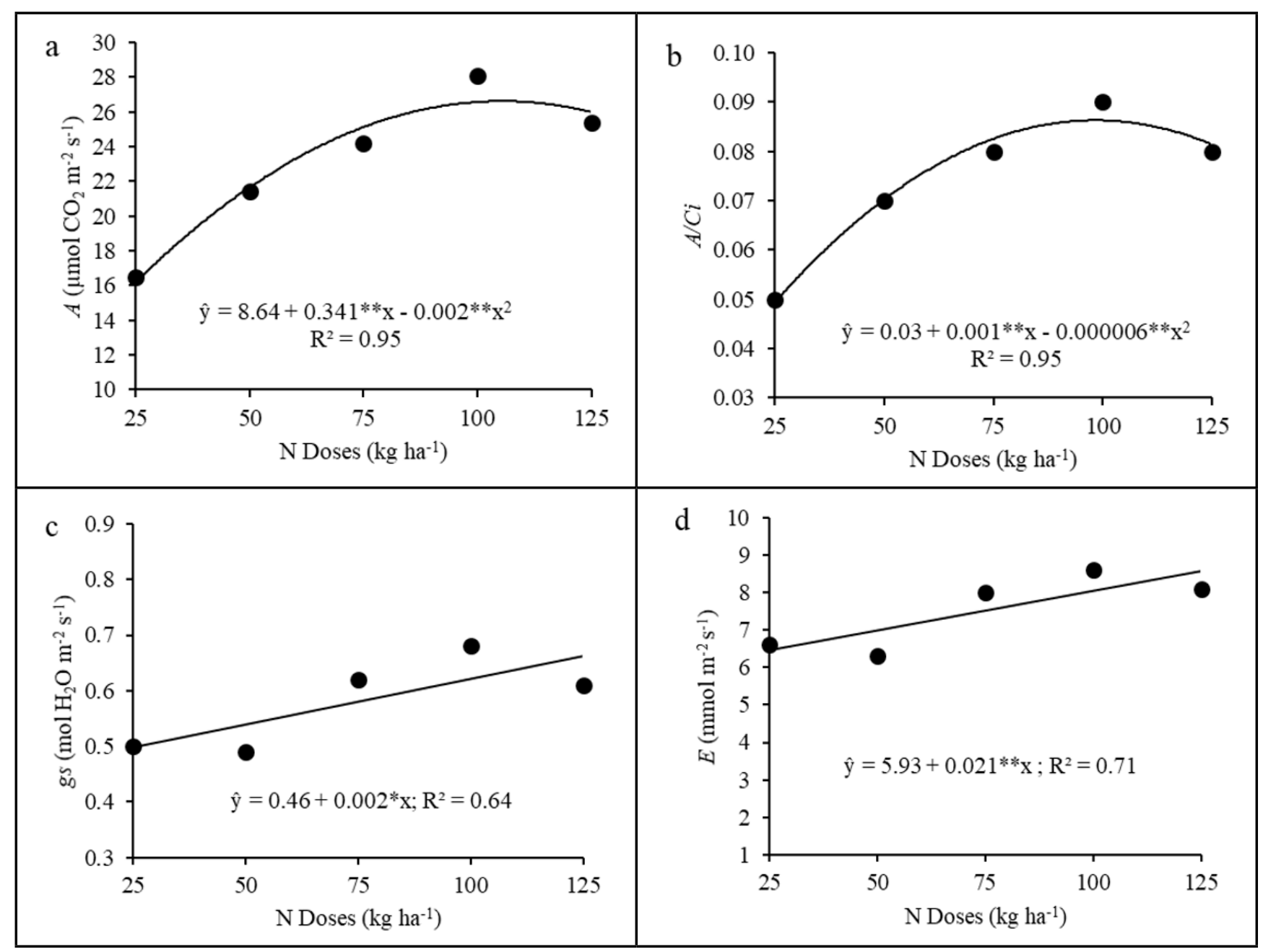

Figure 1. Net photosynthesis (A; a), Instant carboxylation efficiency (A/Ci; b), Stomatal conductance (gs; c) and Transpiration (E; d) of basil plants in relation to $\mathrm{N}$ doses. ${ }^{* *}$ significant at $1 \%$ by the $\mathrm{t}$ test. Fortaleza, UFC, 2015.

(23.1 $\mu \mathrm{mol} \mathrm{CO}_{2} \mathrm{~m}^{-2} \mathrm{~s}^{-1}$ and 0.07$)$ at doses of 85.3 and $83.3 \mathrm{~kg} \mathrm{ha}^{-1}$ $\mathrm{N}$, respectively, representing an increase of, approximately, $40 \%$ for photosynthesis and instantaneous carboxylation efficiency in relation to the values obtained $\left(16.5 \mu \mathrm{mol} \mathrm{CO}_{2} \mathrm{~m}^{-2}\right.$ $\mathrm{s}^{-1}$ and 0.05$)$ at the lowest dose tested in this experiment $\left(25 \mathrm{~kg} \mathrm{ha}^{-1} \mathrm{~N}\right)$. On the other hand, stomatal conductance (Figure 1c) and transpiration (Figure 1d) increased linearly with an increase of soil $\mathrm{N}$ availability.

The decrease in photosynthesis rate (Figure 1a) using the optimum dose $\left(85.3 \mathrm{~kg} \mathrm{ha}^{-1} \mathrm{~N}\right)$, can be related to a possible biochemical limitation due to an unbalanced nutrition (Marschner, 2012; Taiz et al., 2017). Thus, no relationship to stomatal restrictions was noticed, as an increase in stomatal conductance was observed with an increase of $\mathrm{N}$ doses
(Figure 1c), which may have allowed a greater $\mathrm{CO}_{2}$ diffusion in the stomatal pore cavity. This biochemical limitation can be reinforced by the reduction of instantaneous carboxylation efficiency using the estimated dose of $83.3 \mathrm{~kg} \mathrm{ha}^{-1}$ $\mathrm{N}$ (Figure 1b), which shows that this concentration is close to the best dose for photosynthesis. On the other hand, with a low soil-N availability, such as the dose of $25 \mathrm{~kg} \mathrm{ha}^{-1}$, we verified a decrease in leaf physiological parameters, showing that the plant primary metabolism is limited by its low availability in the soil, which was also observed by Argyropoulou et al. (2015) for sweet basil (Ocimum basilicum) plants. These researchers observed lower photosynthesis rate, transpiration and stomatal conductance for treatments with a lower $\mathrm{N}$ concentration of the nutrient solution.

For plant height, the maximum average growth was $79 \mathrm{~cm}$ at the dose of 65.7 $\mathrm{kg} \mathrm{ha}^{-1} \mathrm{~N}$ (Figure 2). The shoot area development with $\mathrm{N}$ supply, to some degree, reflects the increase in the plant photosynthesis rate (Figure 1a), highlighting the interaction concerning the plant metabolism, the energy state and its growth (Taiz et al., 2017); however, basil plants did not respond to $\mathrm{N}$ availability at the dose of $65.7 \mathrm{~kg} \mathrm{ha}^{-1}$, suggesting that the crop development is regulated by other factors, besides the additional $\mathrm{N}$ supply. This result corroborates other studies, in which basil was little responsive in relation to growth considering an increased soil N (Sifola \& Barbieri, 2006; Acharya et al., 2020). Thus, we believe that under additional $\mathrm{N}$ supply, in vegetative phase, basil may direct a small concentration of $\mathrm{N}$ to shoot elongation, allocating the surplus to the formation of other organs, especially the leaves (Acharya et al., 2020). 


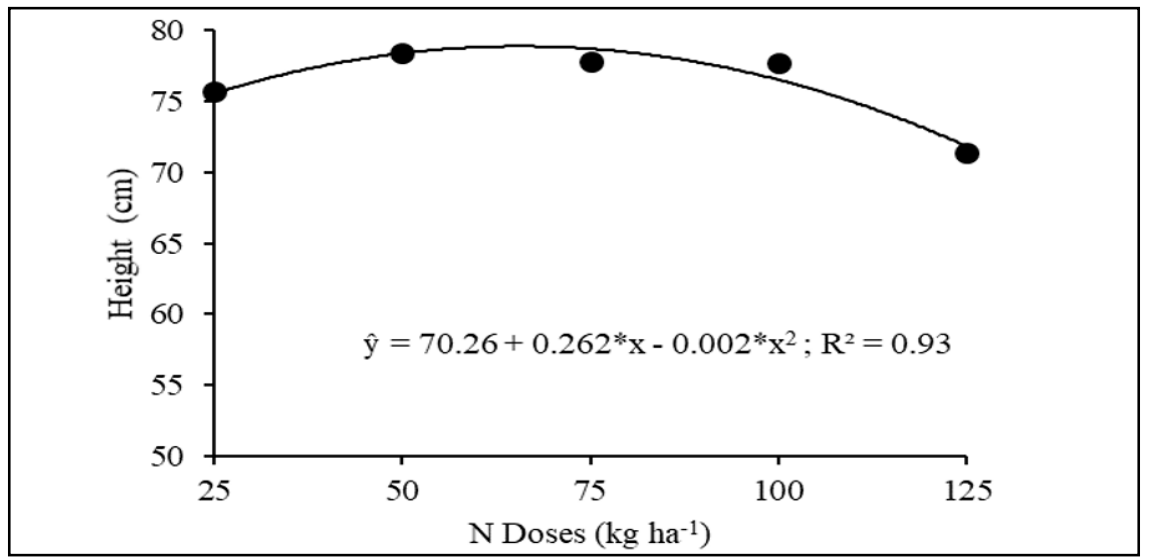

Figure 2. Height of basil plants in relation to increasing $\mathrm{N}$ doses. * significant at $5 \%$ by $\mathrm{t}$ test. Fortaleza, UFC, 2015.

For shoot fresh (Figure 3a) and dry (Figure 3b) masses, the authors observed that with an increase of soil $\mathrm{N}$ availability, increases were verified, videlicet, maximum of $814.1 \mathrm{~g}$ plant $^{-1}$ and $111.4 \mathrm{~g} \mathrm{plant}^{-1}$ under 86.2 and $80.2 \mathrm{~kg} \mathrm{ha}^{-1} \mathrm{~N}$, respectively. These variations can be related to functions of nitrogen in plant, in processes such as photosynthesis, respiration, ionic absorption, as well as protein formation (Marschner, 2012). Thus, we observed that the use of both high or low $\mathrm{N}$ doses (Figures 1 and 2), in basil crop, can impact negatively on physiological and productive responses of the plant to the nutrient and, consequently, decrease the efficiency of the nutrient use (Marschner, 2012). Increases of shoot dry mass of sweet basil resulted from an increase of soil $\mathrm{N}$, reported by Matsumoto et al. (2013), being the doses adjusted to a quadratic model with a peak at $92.2 \mathrm{~kg} \mathrm{ha}^{-1} \mathrm{~N}$. Ferreira et al. (2016) observed variation in the accumulation of shoot dry and fresh masses, due to $\mathrm{N}$ supply, for basil cv. Alfavaca basilicão vermelho, and the highest contents of the element, in soil, resulted in highest accumulations of masses in basil, up to doses of 109.4 and $131.0 \mathrm{~kg} \mathrm{ha}^{-1} \mathrm{~N}$, respectively. Guerra et al. (2020) reported that the dose of 100 $\mathrm{kg} \mathrm{ha}^{-1}$ provided higher accumulation of shoot fresh and dry masses of basil in the first cut. As observed in this study, the cited authors also highlighted that, using maximum and optimum doses, increasing doses results in a decrease in mass accumulation, which can be related to excessive application of nitrogen, as when the optimal level is exceeded, luxury consumption can occur, and, as a consequence, toxicity.

Furthermore, the authors highlight that in relation to optimal doses which had provided higher fresh mass accumulation in shoots, mentioned in the studies and the results found in this study, can be related to the genetic potential of each variety and/ or cultivar, which can result in different responses concerning the efficient use of nitrogen (Blank et al., 2010). However, in general, these results show reliable evidences that basil is highly responsive, up to a certain dose, to nitrogen fertilization, considering $\mathrm{N}$, an essential nutrient to keep physiological and productive responses of the crop (Argyropoulou et al., 2015).

The maximum productivity found was $4.4 \mathrm{t} \mathrm{ha}^{-1}$ at a dose of $82.5 \mathrm{~kg}$ $\mathrm{ha}^{-1} \mathrm{~N}$ (Figure 4). The productivity curve behavior obtained in this study was also reported by Ferreira et al. (2016), showing that an increase of $\mathrm{N}$ supply in two growing seasons affected the productivity of basil cv. Alfavaca basilicão vermelho, observing increasing responses as soil $\mathrm{N}$ availability increases, obtaining the maximum response at the dose of 110 $\mathrm{kg} \mathrm{ha}^{-1}$.

In short, an increase in productivity found in this study, in response to increasing doses of $\mathrm{N}$, as well as by other authors (Matsumoto et al., 2013; Ferreira et al., 2016; Rahimikhoob et al., 2020), showed relation with functions of nitrogen, as in the biosynthesis of amino acids and proteins, nitrogenous bases and plant membranes (Marschner, 2012). Thus, in this study, the increases

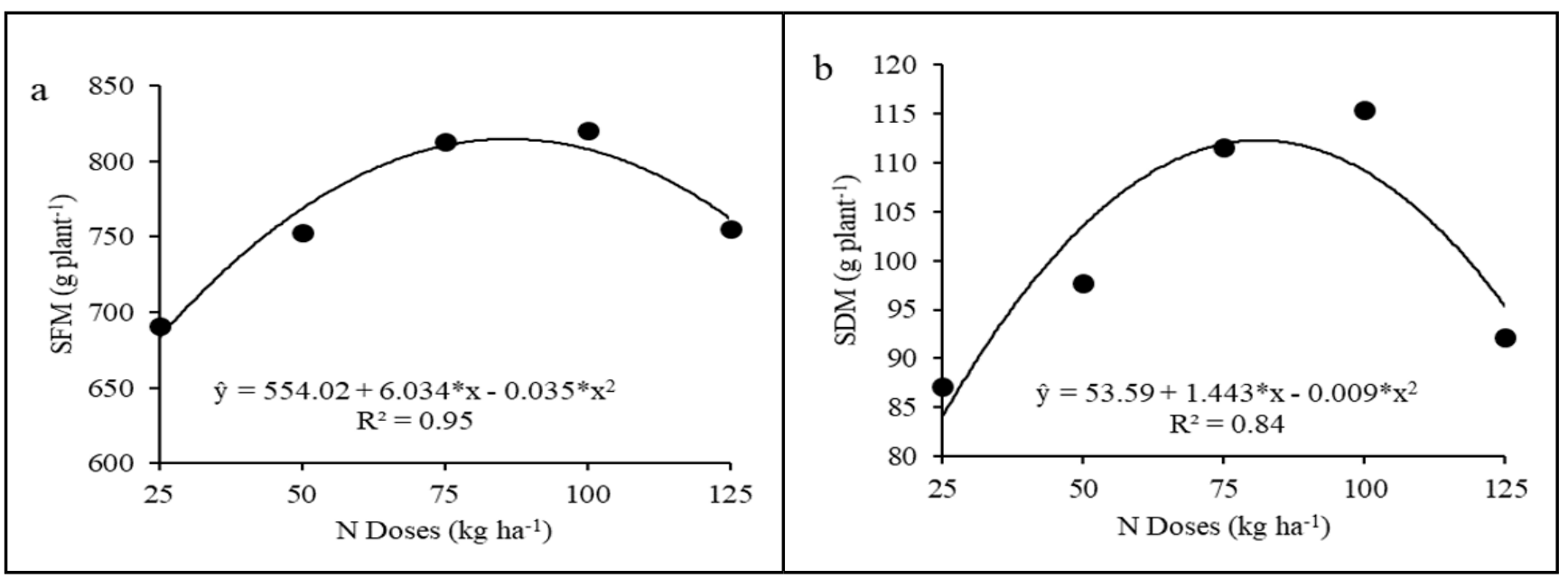

Figure 3. Shoot fresh mass (a) and shoot dry mass (b) of basil plants in relation to increasing $\mathrm{N}$ doses. *significant at $5 \%$ by t test. Fortaleza, UFC, 2015. 


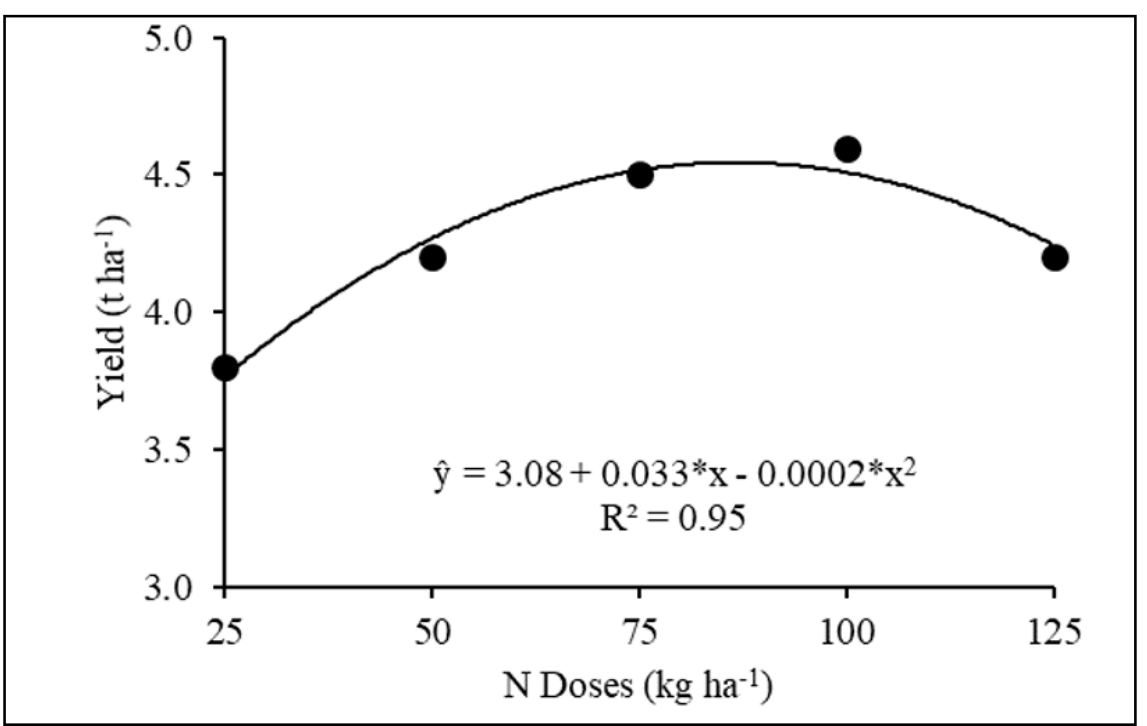

Figure 4. Productivity of fresh biomass of basil in relation to increasing $\mathrm{N}$ doses. *significant at $5 \%$ by t test. Fortaleza, UFC, 2015.

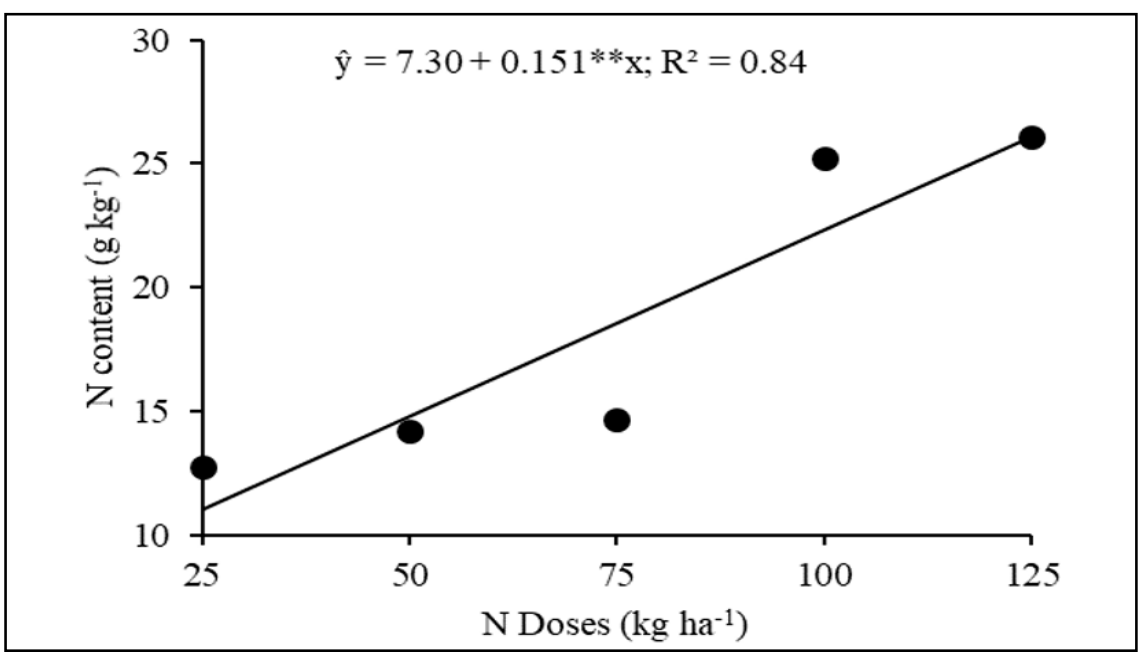

Figure 5. $\mathrm{N}$ content in the shoot of basil plants in relation to $\mathrm{N}$ doses. $* *$ significant at $1 \%$ by $\mathrm{t}$ test. Fortaleza, UFC, 2015.

observed in physiological responses, as soil $\mathrm{N}$ availability increased (Figure 1), allow forming new tissues, providing an increase of productivity (Figure 4).

The highest $\mathrm{N}$ content in the shoot area $\left(26.1 \mathrm{~g} \mathrm{~kg}^{-1}\right)$ was observed at a dose of $125 \mathrm{~kg} \mathrm{ha}^{-1} \mathrm{~N}$ (Figure 5). When $\mathrm{N}$ is available in the uptake system, the plant tends to absorb this nutrient at levels higher than its own demand, storing it in the vacuole in the form of $\mathrm{NO}_{3}^{-}$(Marschner, 2012); this process can explain the relation between the highest $\mathrm{N}$ content obtained using the highest dose of $\mathrm{N}$ in this experiment. So, we verified that variations in $\mathrm{N}$ contents, in the shoot area, obtained in this study, influenced on growth, gas exchanges and productivity of basil and that the highest content obtained at a dose of $125 \mathrm{~kg} \mathrm{ha}^{-1} \mathrm{~N}$ did not result in greater responses of these traits, suggesting that excessive application of $\mathrm{N}$ in the soil exceeded the limit considered tolerable by the plant, reinforcing the hypothesis that other factors are related to possible interactions of this nutrient with others in the uptake process, as well as an increase in the amount of energy input for the assimilation and production of nitrogenous organic molecules (Saloner \& Bernstein, 2020), contributing for a reduction in basil productivity at high levels of soil N (Figure 4).
Given the above, the authors highlight the importance of the nutritional management of basil crop for an increased efficiency of production. Thus, $\mathrm{N}$ supply provides an increase in growth, productivity and gas exchange of basil cv. Italiano Genovese, considering the highest productivity $\left(4.44 \mathrm{t} \mathrm{ha}^{-1}\right)$ noticed at a dose of 82.5 $\mathrm{kg} \mathrm{ha}^{-1} \mathrm{~N}$.

\section{ACKNOWLEDGMENTS}

To the Amazon Foundation for Study and Research Support (FAPESPA) for granting the doctoral scholarship, ICAAF n ${ }^{\circ} 009 / 2017$, to the first author. To The National Council for Scientific and Technological Development (CNPq), for granting scholarship to the other authors.

\section{REFERENCES}

ACHARYA, TP; REITER, MS; WELBAUM, G; ARANCIBIA, RA. 2020. Nitrogen uptake and use efficiency in sweet basil production under low tunnels. HortScience 55: 429-435.

ALVARES, CA; STAPE, JL; SENTELHAS, PC; GONÇALVES, JLM; SPAROVEK, G. 2013. Köppen's climate classification map for Brazil. Meteorologische Zeitschrift 22: 711-728.

ARGYROPOULOU, K.; SALAHAS G.; HELA, D.; PAPASAVVAS, A. 2015. Impact of nitrogen deficiency on biomass production, morphological and biochemical characteristics of sweet basil (Ocimum basilicum L.) plants, cultivated aeroponically. Agriculture \& Food 3: 1314-8591.

BASSI, D; MENOSSI, M; MATTIELO, L. 2018. Nitrogen supply influences photosynthesis establishment along the sugarcane leaf. Scientific Reports 8: 1-13.

BEATOVIĆ, D; KRSTIĆ-MILOŠEVIĆ, D; TRIFUNOVIĆ, S; ŠILJEGOVIĆ, J; GLAMOČLIJA, J; RISTIĆ, M; JELAČIĆ, S. 2015. Chemical composition, antioxidant and antimicrobial activities of the essential oils of twelve Ocimum basilicum L. cultivars grown in Serbia. Records of Natural Products 9: 62-75.

BLANK, AF; SOUZA, EM; PAULA, JWA; ALVES, PB. 2010. Comportamento fenotípico e genotípico de populações de manjericão. Horticultura Brasileira 28: 305-310.

FERREIRA, DF. 2011. Sisvar: a computer statistical analysis system. Ciência e Agrotecnologia 160: 1039-1042.

FERREIRA, SD; BULEGON, LG; YASSUE, RM; ECHER, MM. 2016. Efeito da adubação nitrogenada e da sazonalidade na produtividade de Ocimum basilicum L. Revista Brasileira de 
Plantas Medicinais 18: 67-73.

FERREIRA, SD; ECHER, MM; BULEGON, LG; PASTÓRIO, MA. EGEWARTH, VA; YASSUE, RM; ACHRE, D. 2015. Influência da adubação nitrogenada e época de cultivo sobre o rendimento de folhas de manjericão (Ocimum basilicum var. Verde Toscana) para fins medicinais. Revista Cubana de Plantas Medicinais 20: 389-396.

GUERRA, ANMN; EVANGELISTA, RS; SILVA, MGM; SANTOS, DS. 2020. Nitrogênio influencia o acúmulo de biomassa e o rendimento de óleo essencial de manjericão. Brazilian Journal of Development 6: 24739 $-24756$.

JADON, P; SELLADURAI, R; YADAV, S; COUMAR, M; DOTANIYA, M; SINGH, A; BHADOURIYA, J; KUNDU, S. 2018. Volatilization and leaching losses of nitrogen from different coated urea fertilizers. Journal of Soil Science and Plant Nutrition 18: 10361047.

LAMBERS, H; CHAPIN III, FS; PONS, TL. 2008. Plant Physiological Ecology. New York, USA: Springer.

LEGHARI, SJ; WAHOCHO, NA; LAGHARI, GM; LAGHARI, AH; BHABHAN, GM; TALPUR, KH; BHUTTO, TA; WAHOCHO,
AS; LASHARI, AA. 2016. Role of nitrogen for plant growth and development: a review. Advances in Environmental Biology 10: 209-218.

LUZ, JMQ; MORAIS, TPS; BLANK, AF; SODRÉ, ACB; OLIVEIRA, GS. 2009. Teor, rendimento e composição química do óleo essencial de manjericão sob doses de cama de frango. Horticultura Brasileira 27: 349-353.

MARSCHNER, P. 2012. Marschner's mineral nutrition of higher plants. 3. ed. London UK: Academic Press 651p.

MATSUMOTO, SN; ARAUJO, GS; VIANA, AES. 2013. Growth of sweet basil depending on nitrogen and potassium doses. Horticultura Brasileira 31: 489-493.

PAIVA, EP; MAIA, SSS; CUNHA, CSM; COELHO, MFB; SILVA, FM. 2011. Composição do substrato para o desenvolvimento de mudas de manjericão (Ocimum basilicum L.). Revista Caatinga 24: 62-67.

PEREIRA, RCA; MOREIRA, ALM. 2011. Manjericão: cultivo e utilização. Embrapa Agroindústria Tropical, Fortaleza. 31p.

RAHIMIKHOO H; SOHRABI, T; DELSHAD, M. 2020. Development of a critical nitrogen dilution curve for basil (Ocimum basilicum
L.) under greenhouse conditions. Journal of Soil Science and Plant Nutrition 20: 881-891.

RUAN, L; WEI, K; WANG, L; CHENG, H; ZHANG, F; WU, L; BAI, P; ZHANG, C. 2016. Characteristics of $\mathrm{NH}_{4}+$ and $\mathrm{NO}^{-}-$fluxes in tea (Camellia sinensis) roots measured by scanning ion-selective electrode technique. Scientific Reports 6: 1-8.

SALONER, A; BERNSTEIN, N. 2020. Response of medical cannabis (Cannabis sativa $\mathrm{L}$.) to nitrogen supply under long photoperiod. Frontiers in Plant Science 11: 1-15.

SIFOLA, MI; BARBIERI, G. 2006. Growth, yield and essential oil content of three cultivars of basil grown under different levels of nitrogen in the field. Scientia Horticulturae 108: 408-413.

SILVA, FCDS. (ed). 2009. Manual of chemical analysis of soils, plants and fertilizers. Embrapa Solos. 627p.

TAIZ, L; ZEIGER, E; MOLLER, IM; MURPHY, A. 2017. Fisiologia e desenvolvimento vegetal. 6 ed. Porto Alegre: Artmed, 888p.

VELOSO, RA. 2012. Divergência genética, análise do óleo essencial e bioatividade de acessos de manjericão (Ocimum basilicum L.) no Estado do Tocantins. Gurupi-TO: Universidade Federal de Tocantins. 93p (M.Sc. dissertation). 